\title{
The Use of Social Networks Sites (SNSs) among University Students: How Far do They Learn
}

\author{
Sharifah Sariah Syed Hassan and Zahra Mardani Landani
}

\begin{abstract}
The study investigated the pedagogical affordances of SNS and its relationship on student engagement. A sample of 300 students responded to this quantitative research using a self constructed questionnaire. The hypothesized model has been tested to determine the relationships between pedagogical affordances and student engagement. This model underpins the theory of constructivist of interactions that promote learning; connectivity and collaboration through Web 2.0 technology. Using Multiple Regression Analysis, the model is able to explain the significant relationships of connectivity, assessment and feedback and collaboration in predicting student engagement when learning via SNS. The implications of the study are discussed based on theory, practical importance and methodology of research.
\end{abstract}

Index Terms-Social network sites (SNSs), pedagogical affordances, communication, assessment and collaboration.

\section{INTRODUCTION}

The advancement of Internet based-mobile technology and the new trend of its operating system have given a new wave to the evolution of social communications and teaching and learning. In the context of learning, social networks and media have widely been investigated in the context of student engagement [1], [2], social learning resources [3]; and online communal knowledge sharing [4]. Despite words limitation and geographical distance, social network sites have been used to bridge the communication and connections [5], and teachers can build rapport with their students through encouraging discussion and show availability [6]. However, there is still lack of empirical evidence on the extent of the pedagogical potentials to be materialized in the social networks. Thus, this study intends to investigate the extent of the pedagogical affordances adopted by the Higher learning lecturers via social networks.

To approach learning via social networks, the literatures have shown that student centered learning can take place where students discover, create, share, and collaborate information.

However, different applications offer different pedagogical potentials. Table I provides the applications of SNSs in teaching and previous related research. The preferences of usage are based on the potential of communication, feedback and comments, attachment of short and long videos and expanding relationships and social

Manuscript received January 9, 2014; revised March 11, 2014. This manuscript is originally written for the purpose of this conference and journal submission. This research has been designed and sponsored by the researchers.

The authors are with the International Islamic University Malaysia (e-mail: sariah1199@ yahoo.com, sharifahshahab@iium.edu.my, hediye_mus54@yahoo.com). networking.

TABLE I: APPLICATIONS OF SNSS IN T\&L AND LITERATURES

\begin{tabular}{|c|l|c|}
\hline SNSs & Applications & Research \\
\hline Blog & $\begin{array}{l}\text { e-portfolio and journal entry. } \\
\text { Video and picture attachments. }\end{array}$ & [7], [8]. \\
\hline \multirow{2}{*}{ Facebook } & $\begin{array}{l}\text { Communications synchronous } \\
\text { and asynchronous. Attachment } \\
\text { short videos, pictures, document } \\
\text { files. }\end{array}$ & {$[9],[10]$.} \\
\hline YouTube & $\begin{array}{l}\text { Short message, sharing } \\
\text { documents and files through } \\
\text { Filesocial. }\end{array}$ & $\begin{array}{l}\text { Video sharing, comments and } \\
\text { feedback }\end{array}$ \\
\hline
\end{tabular}

Among students who are taking online courses, [14] assert that they also spend more time using online tools and social media when compared with traditional face to face students. In another aspect, [15], [16] propose that social media can enhance critical thinking and collaboration through creating and sharing knowledge among peers. Thus, the establishment of social connections and virtual relationships play vital role on learning [17].

In terms of efficiency, social network work sites work well in dealing with learning process where there is ease of use interface. Without the need of advance knowledge and skills, SNSs such as Facebook can easily be used to aggregate information through the technology of RSS (Real Simple Syndication). The latest updates and information can be notified easily through smart phone without the need to log in the SNSs. It is important to note however, the use of social networks sites among University students need to be done with certain precaution. Instead of learning about the information they are supposed to learn, students are also prone to be distracted which renders the learning process to be hindered. Study conducted by [18] demonstrates that only $17 \%$ of college students used Facebook to learn new information. On the contrary, [19] has analyzed the literatures related to the potential use of SNSs in teaching and learning. They suggest on educators to promote creativity and to assess students' activities. Thus, how and the way they learn via SNSs must be well articulated and underpinned according to theories and framework.

\section{CONCEPTUAL FRAMEWORK}

This study expanded [2] and [1]'s pedagogical affordances of Web 2.0 by integrating assessment and feedback in the context of social networks. Based on constructivist theory by [20] cited in [21], there are three ways of cultural tools that promote learning; imitative learning, instructed learning and collaborative learning. Imitative learning relates to following what others do. Instructed learning involves instructions from 
a teacher. Collaborative learning involves working together in a group. Parallel with [1], [20] introduces the pedagogical affordances in Web 2.0 learning environment. Connectivity relates to engaging reflective dialogue and building social rapport. Collaboration and knowledge sharing include sharing resources and task completion in group. Engagement involves student satisfaction and enjoyment. In this study, assessment and feedback are integrated. Fig. 1 illustrates the hypothesized model. The research intends to explain the model and identify the relationships of the affordances with student engagement via SNSs.

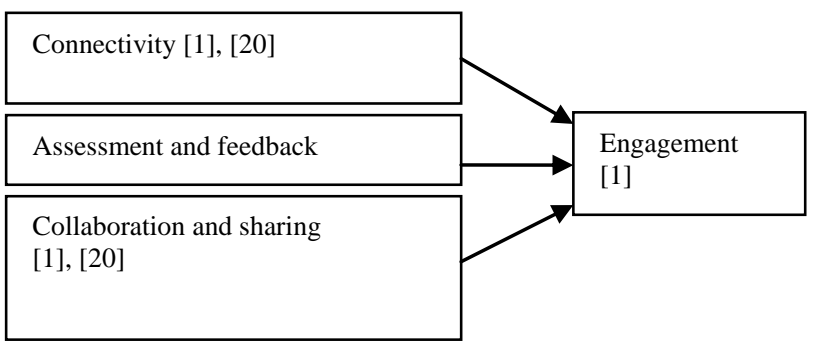

Fig. 1. Model of student engagement via SNS.

\section{RESEARCH DESIGN}

The study has developed a set of questionnaire with 28 items to measure connectivity, assessment and feedback, collaboration and engagement. The questionnaires with 5-Likert scale ranging from strongly disagree to strongly agree have been distributed to 400 students in a University in Kuala Lumpur. The selection of students has been identified upon the information given on the use of SNS from the respective faculty. A neutral scale of 3 is designated to the questionnaire. This survey research has addressed the content, construct validity and reliability of the instrument or questionnaire.

\section{ANALYSIS PROCEDURE}

The SPSS version 16.0 has been utilized to display the descriptive and inferential statistics. The strongly agree and agree; strongly disagree and disagree are then collapsed in a separate group to show agreement percentage from the respondents. Mean and standard deviation are also computed to show the dispersion of data.

The Multiple linear regression analysis (MRA) is computed to show the model variance explained. The predictors are determined using significant value $p<0.05$. Overall explanation is also referred to ANOVA (analysis of variance) based on the output of MRA using F ratio of two mean square values.

\section{RESUlTS}

\section{A. Descriptive Statistics: Breakdown Information of Respondents and Trend of SNS Usage}

Out of 400 questionnaires distributed, only 300 responded to the survey. Table II represents the trend of SNS usage daily. It is reported most of the University students (45.3\%) use SNS within less than an hour daily.
TABLE II: DAILY USAGE OF SNS

\begin{tabular}{lrr}
\hline & Frequency & Percent \\
\hline Less than 1 hour & 136 & 45.3 \\
\hline Between 1 to 2 hours & 116 & 38.7 \\
\hline More than 2 hours & 43 & 14.3 \\
\hline Total & 300 & 100.0 \\
\hline
\end{tabular}

To identify the detail responses of each item in pedagogical affordances, the results show that $70 \%$ of the students agree that SNS improve their communication skills (see Table II).The least is $54 \%$ of the students agree that they can send draft of assignment via SNS. However, the trend of students to choose neutral is obvious with at least 30 to 35 percent. Thus, they are not sure in deciding about the use of SNS in the classroom.

TABLE III: PERCENTAGE OF COLLAPSED DISAGREE AND AGREE

\begin{tabular}{lll}
\hline Connectivity & \% Disagree & $\%$ Agree \\
\hline Access bigger audience & 8 & 65 \\
\hline New relationship & 5 & 63 \\
\hline Improve communication skills & 6 & 70 \\
\hline $\begin{array}{l}\text { Create friendship beyond learning } \\
\text { community }\end{array}$ & 10 & 67 \\
\hline Good rapport with lecturer & 8 & 65 \\
\hline Assignment and Feedback & & \\
\hline Submit assignment & 6. & 66 \\
\hline Information about assignment & 11 & 67 \\
\hline Send draft of assignment & 12 & 54 \\
\hline Give feedback/comments & 6 & 64 \\
\hline Collaboration and Sharing & & \\
\hline Learning resources & 33 & 67 \\
\hline Share links & 10 & 61 \\
\hline Can comment on other peers & 14 & 58 \\
\hline Can share ideas with others & 12 & 58 \\
\hline Get latest updates & 7 & 66 \\
\hline
\end{tabular}

Note: lowest Mean of 5-Likert scale is 3.57(encourage to send draft of assignment). The highest Mean is 3.84 (improve communication skills). Standard deviation ranges from 0.8 to 1.1 .

\section{B. Inferential Statistics}

TABLE IV: LINEAR REGRESSION

\begin{tabular}{|c|c|c|c|c|c|}
\hline \multicolumn{6}{|c|}{ Coefficients $^{\mathrm{a}}$} \\
\hline \multirow[t]{2}{*}{ Model } & & $\begin{array}{l}\text { andardized } \\
\text { fficients }\end{array}$ & Std. Coef & & \\
\hline & $\mathrm{B}$ & Std. Error & Beta & $\mathrm{t}$ & Sig. \\
\hline 1 (Constant) & 0.082 & 0.116 & & 0.704 & 0.482 \\
\hline CCMEAN & 0.274 & 0.039 & 0.258 & 7.023 & 0.000 \\
\hline CAMEAN & 0.127 & 0.056 & 0.110 & 2.272 & 0.024 \\
\hline CRMEAN & 0.572 & 0.046 & 0.604 & 12.456 & 0.000 \\
\hline
\end{tabular}

a. Dependent Variable: DRESULT

To address the hypothesized model in predicting student engagement via SNS, a linear regression in Table IV shows the relationships. The MRA with all the predictors (connectivity, feedback and sharing) produce $R^{2}=81.2 \%$ variance explained in student engagement. Thus, the results $\mathrm{F}$ $(3,36)=424.42, p<0.01$; indicate a significant model with each relationship contributes to the explanation of the model. Connectivity $(\beta=0.258)$ influences student engagement 
significantly. Followed by feedback $(\beta=0.110)$ and sharing $(\beta=0.604)$.

\section{DISCUSSIONS}

The study has empirically proven that pedagogical affordances when practiced by the lecturers will promote student engagement. These pedagogical potentials in SNS allow students not only to expand relationships beyond the classroom but also to improve their communication skills.

Thus, despite the limitation of words and distance as the barriers towards the use of SNS in teaching and learning, the findings show that students are able to connect themselves with the learning content and the lecturer. This is parallel with [5] and [22] where technology is said to gauge the connections among students and teacher.

The connectivity where students can access to bigger audience and create new relationships, improve communication skills and build a good rapport with students is evidently proven to take place in the study (more than $60 \%$ agree). The significant relationship between connectivity and student engagement $(\beta=0.26)$ shows that interactions between student and student; and student and teacher promote student learning in SNS environment. This also parallel with [23] where he believes that interaction is the key factor for a success in learning at distance.

In terms of assignment and feedback, only 54\% of the students show agreement. It can be included that not many lecturers use SNS as a platform for sending draft assignment. The relationship between assignment and feedback with student engagement is significant $(\beta=0.11)$ but does not carry the practical significance. Thus, the possibility to prove further on the assignment and feedback provided by the lecturers via SNS need to be properly addressed in future research.

In terms of collaboration and sharing, only $58 \%$ of the students agree that their lecturers allow them to make comments to other peers and share ideas with others. Through SNS, lecturers use the platform to disseminate links to resources, allow students to share information with the learning community and give updates to students. The strength of the relationship between collaboration and student engagement is the highest $(\beta=0.60)$. [20], [21] have emphasized on collaboration as the basis of constructivist learning. Learning in a group will allow two way interactions among students. Students are believed to learn from and among them. They disseminate information, create new ideas and formulate new content.

\section{IMPLICATIONS OF STUDY}

This study applies to the new context of learning using SNS. However, different type of SNS has different applications and implications. Thus, future research needs to address specific type of SNS in order to investigate the effectiveness of the applications on student learning.

The findings of the research provide a benchmark in empirical data to prove the framework of pedagogical affordances or potentials. More robust research is needed in addressing the validation of items using structural equation modeling analysis. The integration of [1] and [20] frameworks have given new paradigm of research in SNS and Web 2.0 learning environment.

The findings of the study have shown that lecturers do not emphasize strongly on assessment and feedback. Thus, more effort is needed to strategize teaching for constructivist learning environment where assessment is the integral part of learning.

\section{CONCLUSION}

This study has utilized a quantitative approach to reveal model explanation and relationships of the independent (pedagogical affordances) and dependent variable (student engagement). The model indicates good variance explained with $82 \%$. All the relationships are also significant. However, assessment and feedback factor does not carry practical significance due to low contribution to student engagement. Recommendations for future research include adding more questions related to all the factors. Further robust research using more involvement from many Universities is needed.

\section{REFERENCES}

[1] C. McLoughlin and M. J. W. Lee, "Personalised and self-regulated learning in the web 2.0 Era: International exemplars of innovative pedagogy using social software," Australasian Journal of Educational Technology, vol. 26, no. 1, pp. 28-43, 2010.

[2] M. Fisher and D. E. Baird, "Online learning design that fosters student support, self-regulation, and retention," Campus-Wide Information Systems, vol. 22, no. 2, pp. 88-107, 2005.

[3] C. Greenhow and B. Robelia. "Old communication, new literacies: social network sites as social learning resources," Journal of Computer-Mediated Communication, vol. 14, no. 4, pp. 1130-1161, 2009.

[4] S. M. Faraj, C. K. Gerald, and B. Azad, "The contradictory influence of social media affordances on online communal knowledge sharing," Journal of Computer-Mediated Communication, vol. 19, no. 1, pp. 38-55, 2013.

[5] B. Kerhrwald. (2007). The ties that bind: Social presence, relations and productive collaboration in online learning Environments. [Online]. Available: http://www.ascilite.org.au/conferences/singapore07/procs/kehrwald.p df

[6] W. Buskist and B. K. Saville, "Creating positive emotional contexts for enhancing teaching and learning," APS Observer, pp. 12-13, 2001.

[7] D. Churchill, "Educational applications of web 2.0: Using blogs to support teaching and learning," British Journal of Educational Technology, vol. 40, no. 1, pp. 179-183, 2009.

[8] J. B. Williams and J. Jacobs, "Exploring the use of blogs as learning spaces in the higher education sector," Australasian Journal of Educational Technology, vol. 20, no. 2, pp. 232-247, 2004.

[9] B. S. Mathews, "Do you Facebook? Networking with students online," College and Research Libraries News, vol. 37, pp. 306-307, 2006.

[10] J. P. Mazer, R. E. Murphy, and C. J. Simonds, "I'll see you on 'Facebook': The effects of computer-mediated teacher self-disclosure on student motivation, affective learning, and classroom climate," Communication Education, vol. 56, pp. 1-17, 2007.

[11] B. Kerstin, U. Carsten, F. Jinjin, and S. Ruimin, "Microblogging for language learning: learning and for research: principles and prototypes," in Proc. the 17th International Conference on World Wide Web, pp. 705-714, ACM, New York, 2009.

[12] H. S. A. Khalifa, "Twitter in academia: a case study from Saudi Arabia," e-Learn, vol. 9, no. 1, pp. 1-11, 2008.

[13] P. G. Lange, "Publicly private and privately public: social networking on YouTube," Journal of Computer-Mediated Communication, vol. 19, no. 1, pp. 38-55, 2013.

[14] P. D. Chen, A. D. Lambert and K. R. Guidry, "Engaging online learners: The impact of web-based technology on college student engagement," Computer and Education, vol. 54, pp. 1222-1232, 2010.

[15] M. C. Robert, G. D. Kuh, and S. P. Klein, "Student engagement and student learning: Testing the linkages," Research in Higher Education, vol. 47, no. 1, pp. 1-32, 2006. 
[16] S. G. Mazman and Y. K. Usluel, "Modeling educational usage of Facebook," Computers and Education, vol. 55, no. 2, pp. 444-453, 2010.

[17] A. M. Fewkes and M. McCabe, "Facebook: learning tool or distraction?" Journal of Digital Learning in Teacher Education, vol. 28, no. 3, 2012.

[18] T. A. Pempek, Y. A. Yermolayeva, and S. L. Calvert, "College students' social networking experiences on Facebook," Journal of Applied Developmental Psychology, vol. 30, no. 3, pp. 227-238, 2009.

[19] T. Kristen, M. Jessica, and H. Ma. (2013). Effects of Student Engagement with Social Media on Student Learning: A Review of Literature. The Journal of Technology in Student Affairs. [Online]. Available:

http://www.studentaffairs.com/ejournal/Summer_2013/EffectsOfStud entEngagementWithSocialMedia.html

[20] L. S. Vygotsky, Mind in Society, Cambridge, MA: Harvard University Press, 1978.

[21] L. C. Moll, Vygotsky and Education: Instructional Implications and Applications of Socio Historical Psychology, New York: Cambridge University Press, 1994.

[22] P. M. Leonardi, M. Huysman, and C. Steinfield, "Enterprise social media: definition, history, and prospects for the study of social technologies in organizations," Journal of Computer-Mediated Communication, vol, 19, no. 1, pp. 1-19, 2013.

[23] M. G. Moore, "Three types of interaction," The American Journal of Distance Education, vol. 3, no. 2, pp. 1-6, 1989

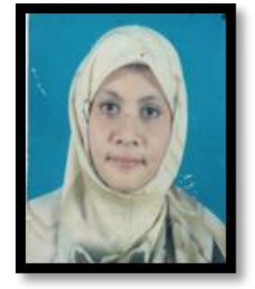

Sharifah Sariah Syed Hassan received her B.Sc. in genetics, University Malaya in 1990. Med. Instructional technology University Malaya in 2000. Dip. Edu Teaching English and maths, International Islamic University Malaysia in 1994 PhD. in instructional technology, International Islamic University Malaysia in 2008. She has 10 years of teaching experience in school. She is now currently working at International Islamic University Malaysia. She has published more than 10 papers for the past four years related to social networks and computer technology in teaching and learning.

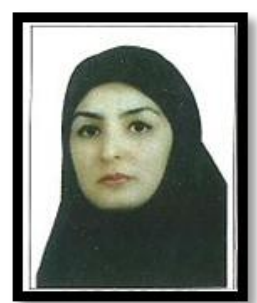

Zahra Mardani Landani was a bachelor in English language-translation, Islamic Azad University-Khorasgan Branch in 1999. She is a master student majoring instructional technology at International Islamic University Malaysia IIUM. She has 10 years of teaching experience in school. She is currently working on research related to social network sites and e-learning. 